The Internal Politics of Journal Editing

\author{
By William A. Barnett \\ University of Kansas, Lawrence, KS and Center for Financial Stability, NY City \\ Editor of Macroeconomic Dynamics
}

September 17, 2009

Revised April 29, 2012

I have been invited to write an essay on my experiences as founder and editor of the Cambridge University Press journal, Macroeconomic Dynamics. I have decided to focus the essay on my experiences in starting up the journal. Few economists, who have not themselves started up a new journal, are aware of the nature of the process and its sometimes very complicated academic politics.

\title{
1. The Conflict
}

As is known to many economists, there was a conflict between another well-known journal and its society at around the time that I started up Macroeconomic Dynamics (MD) in 1996-1997. The journal was the Journal of Economic Dynamics and Control (JEDC). The society was called the Society for Economic Dynamics and Control (SEDC). I was a member of the society and knew people involved on both sides of the conflict. The society wanted to be able to select that journal's editorial board, which presumably meant changing existing members. But the Society did not own the journal. Elsevier owned the journal and wanted to retain control of the editorial board membership. Consequently the society approached Academic Press with a proposal to start up a new journal, with the society being authorized to appoint the editorial board. Tom Cooley was to be the managing editor, and there was to be a heavier emphasis on real business cycle theory than was the case with the JEDC. Academic Press turned down the proposal.

There were bad feelings about this conflict, both within the society and on the journal's editorial board. I called an eminent officer of the society, regarding the society's concerns, and I also called Steve Turnovsky, one of the JEDC journal's editors at the time, regarding the journal's concerns. I explained that I could start up a new journal that would be purely scientific and neutral regarding the differences of opinion between the society and the journal. I explained that I could propose the new journal to Cambridge U. Press, with which I had good relations, as editor of one of that publisher's monograph series. I was advised by the society's officer and by Steve that it would be a good idea, and I should do it as a possible means of solving the problem. I was concerned about the commitment of my time that would be required and whether that commitment was justified. As a result, I asked the society's officer whether the plans to try to start up another new journal by the society would stop, if I produced a neutral scientific macroeconomic journal, with the name Macroeconomic Dynamics. He said that, yes, it would stop and the "plans" were only talk. 


\section{First New Journal}

I proposed the new journal to Cambridge U Press, which accepted the proposal. Next I needed to select a Board of Editors. I selected a group of Advisory Editors and Associate Editors, with the intent of spanning all areas of good macroeconomic science, without any prejudice or identifiable "agenda" in methodology, geography, or politics. Then the problems began. I was lobbied by various Advisory Editors and Associate Editors to make changes in the editorial board. The degree of factionalism surprised me. Not only were there attempts to change the balance towards a particular methodological or political view, but sometimes to change the balance geographically, nationalistically, regionally, racially, or ethnically. There also were gender based pressures. Sometimes the lobbying was directed at perceived underrepresentation of a particular group. When I found that to be justified, I asked for suggestions of economists to be added, and I invited additional board members from that group. More disturbing were pressures to eliminate a minority from representation, so that the journal would represent solely the interests of a particular group, as is the case with many other journals, such as the Journal of Post Keynesian Economics and the Quarterly Journal of Austrian Economics, along with various regional economics journals, such as those published in languages other than English. I was particularly surprised by the lobbying from some of the European board members to discredit and thereby eliminate board members from other European countries. Since a fundamental purpose of this journal was to avoid becoming identified with any such faction or group, I often did the exact opposite by increasing the size of the minority, so that the minority no longer could be marginalized or ignored. Once it had become clear that attempts to eliminate a minority were counterproductive, that kind of lobbying ended. As a result, the Editorial Board became very large and very diverse, with only the sophistication and high tech competency of all members holding them together. To this day, the editorial board of Macroeconomic Dynamics is unusually large and diverse. ${ }^{1}$

\section{Editorial Board Selection Problems}

All seemed to be peaceful, and the journal startup was successful. I then was informed by SEDC's officer, during a telephone call, that he objected to the fact that there were econometricians on the Board of Advisory Editors. He did not object to the fact that the Associate Editors included econometricians, but he did not feel I should be listening to the advice of econometricians on the Board of Advisory Editors. The Advisory Editors included a minority of econometricians, such as Peter Phillips and Ron Gallant, who are among the world's most important econometricians. The SEDC's officer and one of his coauthor also were among the Advisory Editors of Macroeconomic Dynamics. At the same time, Cambridge University Press told me the Board of Advisory Editors was too large. Based upon the pressure from Cambridge University press and my deep respect for the SEDC officer's contributions to the field of macroeconomics, I removed from the Board of Advisory Editors all of the econometricians, except for two: Mark Watson and Adrian Pagan, whose contributions to macroeconomics have been major. Evidently, that was not good enough for the SEDC officer, who resigned from the Board. His coauthor did not resign and is on the journal's board to the present day. The SEDC began again to plan for its own new journal.

\footnotetext{
${ }^{1}$ See http://econ.tepper.cmu.edu/barnett/MDboard.html
} 


\section{Second New Journal}

The SEDC revised its proposal to Academic Press for a new journal. This time instead of proposing only one Editor, Tom Cooley, the society proposed a Board of Coeditors, including all of the present and recent past presidents of the society, such as Ed Prescott and Tom Sargent, along with Tom Cooley. Although it was obvious that most of the coeditors were largely "window dressing" and Tom Cooley was to be the Managing Editor, Academic Press accepted the new proposal. The title of the new journal was to be Economic Dynamics, and the society was to change its name to the Society for Economic Dynamics (SED), with the words "and Control" removed. But Steve Turnovsky, who had close ties with the JEDC, told me the proposed title of the new SED journal was objectionable to the JEDC and in particular to its publisher. This was because, at the time, the JEDC was divided into two sections, one of which was named "Economic Dynamics." As a result, Elsevier, the publisher of the JEDC, had its attorneys contact Academic Press with objections to the proposed title for the new journal. A few weeks later, Steve called me on the phone to inform me that Academic Press had decided to change the name of the new journal to Dynamic Macroeconomics. I was under the impression that the information about the new title came from one of Tom Cooley's students. Steve suggested I inform Cambridge U. Press about the new title. I called Cambridge U. Press and explained that Academic Press was planning to start up a new journal with the name Dynamic Macroeconomics, while I was Editor for Cambridge University Press of the journal, Macroeconomic Dynamics.

\section{Resolution of the Journal-Title-Selection Conflict}

Following the call by the Cambridge attorneys to Academic Press about objections to the name Dynamic Macroeconomics, Steve unexpectedly received a phone call from Academic Press asking him for a suggestion for the new journal's title. He suggested the title, Review of Economic Dynamics. In making this suggestion, he had in mind a somewhat parallel (and harmonious) situation by which the Journal of International Economics was published by Elsevier and the Review of International Economics was published by Blackwell (now part of Wiley). Academic Press accepted that suggestion, and the journal, Review of Economic Dynamics (RED), was born and has subsequently evolved into a fine journal. Instead of just the JEDC, there now were three journals with related objectives, the JEDC, RED, and MD. All that had transpired had its origins in research on the time inconsistency of optimal control policy. That research had motivated much of the former SEDC's objections to the JEDC's publication of papers on optimal control policy and to the role of optimal control theorists, such as David Kendrick and Steve Turnovsky, in founding and editing the JEDC. Paradoxically, both RED and the JEDC now are published by Elsevier, which has bought Academic Press.

\section{Interviews Series}

At the time I started up $M D$, I had to select the sections to be included, such as Book Reviews, Surveys, and Notes. I observed that no peer-reviewed professional journal was publishing interviews with macroeconomists or microeconomists, although Econometric Theory was occasionally publishing interviews with econometricians and the American Statistician was publishing interviews with statisticians. I decided to add an Interviews Section, which occasionally would publish interviews with 
exceptionally important macroeconomists and with those famous microeconomists whose work has been influential in macroeconomics. The choice of those to be interviewed was to depend upon support for the invitation by the journal's Advisory Editors.

Problems arose immediately. It was proposed that the first economist to be interviewed should be Wassily Leontief, since he was at an advanced age and his health was failing. When I proposed interviewing Leontief to the Advisory Editors, there was much opposition to the invitation on the grounds that he was primarily a microeconomist. With little time left to debate the matter and because of his importance in the profession, I decided to adopt a very broad definition of macroeconomics as aggregated microeconomics. There was no other outlet for publication of interviews of famous microeconomists. Leontief's interview was the first we published.

Another microeconomist interviewed early in the evolution of the interviews series was David Cass at the University of Pennsylvania. His interview included use of the four letter $\mathrm{f}$-word in a hostile statement about a former dean at Carnegie Mellon University. The dean's name was mentioned. Cambridge University Press called me and asked if I could get David to tone down his language. He refused and demanded publication of the word exactly as included, on the grounds that the interview was a quotation that could not be changed by the editor, copy editor, or the publisher. Cambridge University did not like the explanation, but agreed that it had to be accepted. The controversial words were typeset in the interview as "f---- you."

From then on, when I invited anyone to be interviewed, I explained the Cass precedent and the fact that people interviewed would be able to say whatever they wanted in a peer-reviewed journal without any peer review at all. Subsequently everyone I've invited to be interviewed has accepted, except for Jean-Michel Grandmont. He complained that the interviews included too many Americans and not enough Europeans. I pointed out that a large percentage of those we had interviewed were born in Europe and moved to America before winning their Nobel Prizes (e.g., Leontief and Modigliani). I did not understand how Jean-Michel's refusal to be interviewed in France was in the best interests of increasing the number of Europeans interviewed within Europe.

The interviews series turned into a collection of interviews of many of the profession's most important stars. As a result of popular demand, Paul Samuelson and I subsequently collected together some of the most interesting of those interviews into a book, Inside the Economist's Mind. Translations of that book, Barnett and Samuelson (2007), have so far been published in Korean, Russian, Chinese, and German, and the book has its own blog. ${ }^{2}$

In addition to the $M D$ Interviews Section, which is unusual among economics journals, Macroeconomic Dynamics includes one other unusual section: the MD Vintage Articles Section, which publishes old unpublished papers that have become citation classics. Although there are not many such papers, there are some that never were published but became heavily cited working papers. Such papers often no longer can meet normal peer review in comparably high quality journals, since those papers tend to overlook more recent research. But because of their established importance, reflected in

\footnotetext{
${ }^{2}$ http://economistmind.blogspot.com/
} 
their heavy citations, those papers are viewed by Macroeconomic Dynamics as meriting easy access in the public domain. The resulting MD Vintage Articles Section, although appearing only infrequently, is very successful, and provides a public service much appreciated by the authors who cite those important papers.

\section{The Present and Future}

While the morphing of one journal into three had its origins in an internal conflict within the profession, the driving force for growth of all three journals since then has been the explosive growth in high quality, scientific research in macroeconomics throughout the world, now including mainland China as well as Taiwan, Singapore, and Hong Kong. All three journals have continued growing rapidly and harmoniously and playing key roles in disseminating high quality research in macroeconomic dynamics.

Did I expect any of this when I agreed to start up Macroeconomic Dynamics? Not at all. 


\section{REFERENCES}

William A. Barnett and Paul A. Samuelson (eds), 2007, Inside the Economist's Mind: Conversations with Eminent Economists, Wiley-Blackwell, New Jersey. 